\title{
Cyganerii Warszawskiej próby wydawnicze, czyli przegląd ,swojskich” czasopism z perspektywy warszawskiej prowincji
}

Co się dzieje w pismach periodycznych? Pusto w nich i głucho jak u łoża konających; zdaje się, że to wszystko pisali ludzie bez siły, bez myśli czy bez odwagi. Z czego się składa zwyczajny ładunek tutejszych periodycznych pism? Z tłumaczeń i naśladowań, na osolenie których często najstosowniej, dorywczym, urywanym sposobem wymyka się jakieś poważne badanie A. Maciejowskiego lub gawęda Wójcickiego; zresztą napotykasz blade jakieś artykuły z podpisami jakichś coraz nowych autorów, cyframi, iksami, które kryją najczęściej jednego i tegoż samego wyrobnika księgarskiego ${ }^{1}$.

Kraszewski opisał w swoim artykule z 1840 roku, jak wyglądało ówczesne czasopiśmiennictwo warszawskie, i wiedział bardzo dobrze, o czym pisze, bo sam pisał i to pisał wiele, tak wiele, że po dziś dzień trudno określić ile ${ }^{2}$. Ukryty za swoimi dwudziestomakilkoma pseudonimami, kryptonimami, inicjałami, różnymi podpisami lub za ich brakiem wiedział, co to naprawdę znaczy być zawodowym literatem, posiadać „rasowy nerw dziennikarski”, odpowiednią technikę, uczestniczyć w ruchu wydawniczym czy to krajowym, czy zagranicznym, wreszcie być pisarzem i jednocześnie znawcą dziennikarstwa ${ }^{3}$. Co więcej, był on naocznym świadkiem procesu, jaki miał wówczas miejsce, procesu kształtowania się zawodu pisarskiego, rodzącej się zależności pomiędzy pisarzem a wydawcą-przedsiębiorcą, dramatem romantyka, który sprzedawać miał, czasami za bezcen, płody swojej myśli, powołanie swe przekuć w profesję, zwierzenia swe mierzyć miarą zadrukowanej kolumny w czasopiśmie „Bóbr”, ody, sonety i hymny niczym kiełbasę kłaść na wadze, pracę

1 J.I. Kraszewski, Krytyka. Literatura w Warszawie, „Tygodnik Petersburski” 1840, nr 54, s. 286

${ }^{2}$ Zob. P. Chmielowski, Spis chronologiczny utworów Kraszewskiego (1830-1887), [w:] J.I. Kraszewski, Wybór pism, oddział 10, Studia i szkice literackie, Warszawa 1894; Józef Ignacy Kraszewski. Zarys bibliograficzny, oprac. S. Stupkiewicz, I. Śliwińska, W. Roszkowska-Sykałowa, Kraków 1966.

3 Zob. A. Trepiński, Józef I. Kraszewski-dziennikarz, „Zeszyty Prasoznawcze” 1960, nr 4, s. $61-62$. 
swego ducha do pracy szwaczki przyrównywać ${ }^{4}$. Cierpiały wówczas cudowne dzieci, cierpieli geniusze, pośrednicy między światem tu i światem tam, kapłani i błaźni, samotni wędrowcy, zaczytani w książkach zbójeckich, obłąkani marzeniami, pijani poezją, „dzieci wieku, mniej lub bardziej dotknięte kiedyś chorobą marzenia”, rozczarowanie i melancholia, osamotnienie i poczucie wyobcowania bowiem stały się dla nich chlebem powszednim, podobnie jak pusty pugilares, który popychał ku czynom niedozwolonym, ku zdradzie, która niepokoiła sumienie ${ }^{6}$. Pochylił się nad biedakami Kraszewski, spoglądając $z$ dalekiej prowincji na ówczesną literaturę francuską i kondycję pisarza, wsłuchiwał się w szepty i krzyki artystów, obserwował procesy zachodzące $\mathrm{w}$,stolicy świata”, sięgał po prasę najnowszą i badał przyczyny, które wpłynęły na zmiany w polskim ruchu wydawniczym ${ }^{7}$.

Na obszarze Królestwa Polskiego w okresie międzypowstaniowym mimo rygorów cenzury, represji politycznych, rewizji, aresztowań, kulturalnej niemocy, likwidacji najważniejszych ośrodków naukowych i oświatowych rozwijał się prężnie rynek prasowo-wydawniczy ${ }^{8}$. I choć większość ówczesnych inicjatyw była krótkotrwała, tytuły prasowe pojawiały się i znikały, często nawet roku na rynku nie będąc, efemeryczne te twory były świadectwem dużej prężności kulturalnej narodu, intensyfikacji życia społeczno-kulturalnego oraz obecności osobliwego uczucia braku, który wywoływał tę aktywność nad wyraz wielką. Dziedzina czasopism społeczno-kulturalnych, a szczególnie tych literackich, bo w ich powstawanie zaangażowani byli cyganie, rozwijała się równie intensywnie, choć w wyniku represji polistopadowych w Królestwie nie ostało się żadne czasopismo tego typu. Nowo powstałe tytuły, najczęściej oficjalnie bezbarwne pod względem ideowym, starały się utrzymywać swoją niezależność poprzez umiarkowanie

${ }^{4}$ Wspominał o tym Jakub Jurkiewicz: „Rzecz prosta, kto pisze w zamiarze odniesienia stąd pewnej korzyści materialnej, ten pracę swoją stawia na równi z przedmiotami kramarskimi: a można tam znaleźć jaki zasiłek moralny, gdzie element utworu sprofanowany został poziomą kupiecką rachubą, gdzie pierwiastek bezinteresowności żadnego nie miał udziału? Ja nigdy nie mogłem zgodzić się powołania Autora z profesją człowieka na chleb pracującego; w moim pojęciu autor, wieszcz prawd moralnych, wyraziciel nieziemskiej na ziemi doskonałości, jest czymś wyższym od zwyczajnych ludzi, a praca ducha w żaden sposób nie kombinuje się z pretensjami jarmarkowej czeladzi”. Zob. B. Dołęga [J. Jurkiewicz], Do Pana Aleksandra Parczewskiego, „Gwiazda” 1847, nr 2, s. L.

5 Ch.A. Sainte-Beuve, ,, Wyznania” Jana Jakuba Rousseau, [w:] idem, Wybór pism krytycznych, przeł. i oprac. A. Jakubiszyn-Tatarkiewiczowa, Warszawa 1957, s. 329.

${ }^{6}$ Zob. A.Z. Makowiecki, Poeta a pieniadz, [w:] Pieniadz w literaturze i teatrze: materiaty z sympozjum ,,Temat pieniądza w literaturze i teatrze”, Uniwersytet Gdański, Gdańsk 17-18 stycznia 2000, red. J. Bachórz, Sopot 2000, s. 157-166.

7 Zob. M. Inglot, Poglady Kraszewskiego na materialne podstawy zawodu pisarskiego (lata 1830-1863), „Zeszyty Prasoznawcze” 1964, z. 1, s. 87-88.

${ }^{8}$ Gdy w roku 1832 w Warszawie wydawano jedenaście tytułów, to trzy lata później liczba ta wzrosła do szesnastu, w kolejnym roku do dziewiętnastu, natomiast w 1841 roku osiągnęła pułap dwudziestu ośmiu tytułów. Istotny spadek zaznaczy się w połowie lat czterdziestych, kiedy to z rynku zniknie aż siedem tytułów. Zob. E. Tomaszewski, Prasa Królestwa Polskiego i ziem litewsko-ruskich okresu międzypowstaniowego (1832-1864), [w:] J. Łojek et al., Prasa polska w latach 1661-1864, Warszawa 1976, s. 111. 
ugodowy charakter ${ }^{9}$, w kwestiach społeczno-kulturalnych przybierały zaś zwykle orientację liberalną, również oficjalnie nieeksponowaną. I kiedy w latach trzydziestych na rynku wydawniczym prym wiódł encyklopedyczny typ czasopisma, które raziło swymi pozostałościami oświeceniowymi i przedpowstaniową romantyczną poetyką, szpalty wypełniał zalew moralno-religijnej problematyki, na scenie artystycznej Warszawy pojawiło się drugie pokolenie romantyków krajowych, które śmiało porywało się ku wielkiemu działaniu ${ }^{10}$ i tym samym dokonało zmian $\mathrm{w}$ czasopiśmiennictwie ${ }^{11}$ i sposobie jego funkcjonowania ${ }^{12}$.

W roku 1840, kiedy cyganie prężnie współpracowali z Hipolitem Skimborowiczem i wypełniali łamy jego czasopism swoimi dziełami, narodził się w głowie Seweryna Filleborna pomysł stworzenia własnego pisma, organu młodych wymierzonego szczególnie w starsze pokolenie twórców, gdzie mumie, „kanapowa koteria", napuszeni brodacze, salonowi mądrale nie mieliby wstępu. Pomysł swój cygan szybko zrealizował - tak też powstał „Nadwiślanin” (choć „Biblioteka Warszawska” spodziewała się „Pioruna” albo „Marcepana Gdańskiego”) ${ }^{13}$, bo bohema nad Wisłą się narodziła, bo to Mazowsze właśnie było celem jej wędrówek, gdzie lud prosty i prawy, z którym bratać się tak chętnie chcieli. Jak głosił podtytuł, był to „pamiętnik literaturze poświęcony”, jak zaś głosiło motto jemu

9 Tę tendencję w prasie polskiej zauważył Piotr Chmielowski: „W kraju dziennikarstwo właściwe, choć liczebnie dość obfite, nie ma aż do r. 1848 żadnej barwy politycznej ani społecznej. Część polityczna gazet jest prostym przekładem $\mathrm{z}$ gazet zagranicznych i to niektórych tylko, $\mathrm{w}$ duchu bardzo konserwatywnym trzymanych; o sprawach wewnętrznych informują one jedynie i to w sposób nader lakoniczny; zdań krytycznych o zagadnieniach najdonioślejszych nie wypowiadają wcale, nawet strona literacka jest w nich zaniedbana”. P. Chmielowski, Publicystyka polska w wieku XIX, „Prawda” 1901, nr 3, s. 45.

${ }^{10} \mathrm{O}$ charakterze debiutantów pisał Dembowski: „Stan warszawskiej literatury najbardziej jest zajmujący, bo walka żywiołów wre, starcie gwałtowne i wszystko pełne życia, zapału i uniesień, choć jeszcze nieprzetrawione. Brak tamtejszej literaturze spokoju i oblicza pełnej godności, jakie osiągnęły dążenia w Wielkopolsce i emigracji, a szarpanie się i niewyrobienie pisarzy warszawskich często razi, lecz za to poświęcenie się całą duszą i wylanie się dla sprawy literatury ojczystej niemało dla nich serc ująć powinno". E. Dembowski, Sprawozdanie z piśmienności polskiej w ciagu 1843 roku, [w:] idem, Pisma, t. 4. Pisma ogłoszone w latach 1844-1846, red. A. Śladkowska, M. Żmigrodzka, Warszawa 1955, s. 6.

11 Tomaszewski od drugiej połowy lat trzydziestych datuje wyraźne zmiany w czasopiśmiennictwie: „wyrażają się one m.in. w odchodzeniu od wersji popularnego magazynu, do bardziej wyspecjalizowanego czasopisma typu systematycznego "przeglądu«, który — odchodząc z wolna od typu encyklopedycznego - zamieszczał materiały bardziej wyspecjalizowane i bardziej reprezentatywne dla określonej tematyki czy też określonego kierunku. W ten sposób czasopiśmiennictwo Królestwa Polskiego dostosowywało się do ewolucji czasopiśmiennictwa zachodnioeuropejskiego. Równocześnie w większym stopniu wprowadzało na swe łamy prace oryginalne i tematykę krajową. Zaczynał się też okres przewagi problematyki literackiej i czasopiśmiennictwa literackiego". E. Tomaszewski, op. cit., s. 152.

12 Należy podkreślić daleko idące zmiany w prowadzeniu systemu kolportażu prasy i sposoby prowadzenia prenumeraty, które pozwoliły uniezależnić się czasopismu od mecenatu. Ibidem, s. 153.

13 Zob. Trz, Pisma periodyczne w Warszawie na r. 1841, „Biblioteka Warszawska” 3, 1841, s. 474. 
przyświecające, było to pismo młodych wymierzone w dyktaturę starszego pokolenia, które wkrótce rozpoczęło polemikę z największym przeciwnikiem inicjatyw Skimborowicza - „Biblioteką Warszawską”

Kto wam uręczył,

Że dopiero życia jesień

Dobrze widzi, dobrze czuje?

Jakby życie bez uniesień

Samej prawdy było wzorem ${ }^{14}$.

„Nadwiślanin” wychodził w Warszawie w drukarni Maksymiliana Chmielewskiego, która mieściła się na ulicy Senatorskiej 463, redakcja zaś znajdowała się w księgarni Dmochowskiego przy ulicy Miodowej 495. Półroczna prenumerata pisma kosztowała 8 złp $^{15}$. Pierwszy tom „Nadwiślanina” składał się z pięciu zeszytów, które ukazywały się począwszy od marca 1841 roku, liczył dwieście cztery strony, tom drugi zaś to jedynie stustronicowy zeszyt, na który złożyły się wydane w 1842 roku poezje i krótkie rozprawy. Myliła się zatem „Biblioteka”, bo „Nadwiślanin” ani dziennikiem, ani miesięcznikiem nie był, regularnie się też nie ukazywał, rację jednak miała, określając format pisma i wskazując na jego wygląd:

Pamiętnik ten wychodzi miesięcznie w małych poszytach, tej prawie, co „Przegląd” objętości i formatu, a nawet ustrojony w taki sam biały jak on zeszłego roku kaftanik, czyli okładkę ${ }^{16}$.

Za redaktora pisma uznano oficjalnie Filleborna ${ }^{17}$, a za współredaktora Romana Zmorskiego, choć pracował on jedynie przy powstaniu pierwszego numeru ${ }^{18}$. Cel „Nadwiślanina” został wyraźnie sformułowany przez Antoniego Filleborna dopiero w drugim tomie pisma, w odpowiedzi na krytykę ze strony „Biblioteki Warszawskiej".

14 Jest to fragment wypowiedzi tytułowego bohatera, Młodzieńca, z dzieła Dominika Magnuszewskiego: „Stary umysł, to zwietrzały! / Dowód, za dowód. / O mistrzu! kto wam uręczył, / Że dopiero życia jesień / Dobrze widzi, dobrze czuje! / Jakby życie bez uniesień, / Samej prawdy było wzorem. / Wolę ogień, co mię pali, / Niż rachubę, co was ziębi. / Bo z nim biegnę wesół... dalej; / Wy z rachubą lgniecie, głębiej, / Życie kończycie wieczorem; / A ja jeszcze w jutro wierzę". Całość stała się mottem drugiego tomu „Nadwiślanina”. Zob. D. Magnuszewski, Wyjątek z poematu dramatycznego pod napisem „,Młodzieniec”, „Ziewonia” 1834, s. 100-101.

15 Nadwiślanin [hasło w:] K. Estreicher, Bibliografia polska XIX stulecia, t. 2, Ł-Q, Kraków 1876, s. 199.

16 Trz, op. cit., s. 474.

17 Na podstawie hasła w Encyklopedii Orgelbranda Straszewska snuje przypuszczenia, jakoby redaktorem „Nadwiślanina” był nie sam Seweryn, lecz Antoni Filleborn („wspólnie z Romanem Zmorskim wydawał pismo pod tytułem »Nadwiślanin, pamiętnik literaturze poświęcony«"), jego brat stryjeczny, thumacz powieści George Sand Leon i Leoni, urzędnik Komisji Rządowej Przychodów i Skarbu. Antoni istotnie współpracował z „Nadwiślaninem”, odpowiadał za administracyjną stronę pisma, jednak nie był jego redaktorem. Zob. Filleborn Antoni [hasło w:] Encyklopedia Powszechna, red. S. Orgelbrand, t. 8, Eck.-Flem, Warszawa 1861, s. 870; M. Straszewska, op. cit., s. 43.

18 Zob. R. Zmorski [oświadczenie], „Nadwiślanin” 1, 1841, s. 96. 
Niech nam będzie wolno z jak największą grzecznością odpowiedzieć, że „Biblioteka” sama jeszcze nie dopięła tego celu — że „Nadwiślanin” jakkolwiek daleki od jej doskonałości nie umieszcza ani poezji z komplementami przed stu laty pisanych, ani artykułów podobnych porankowi modnej kobiety, literackiej wścieklizny itd. O naszym piśmie to tylko powiemy, że celem jego było obudzić zamiłowanie literatury w młodzieży i zwrócić jej usiłowanie ku kształceniu się samoistnemu ${ }^{19}$.

„Biblioteka”, nie uznając „Nadwiślanina” za czasopismo mogące zachwiać jej pozycją, postrzegała cygański twór wydawniczy za pisemko, które „ma zamiar pracować wyłącznie dla samej tylko pięknej literatury”, szczególnie zaś tej, która jest owocem pracy „młodzieży naszej”. W poezji widzi zatem anonimowy komentator punkt podparcia dla „Nadwiślanina”, szczególnie zaś chwali te, których autorem był Filleborn, do prac Zmorskiego zaś odnosi się z dystansem, widzi w nich bowiem ,cierpienia dusz ludzkich”, co go niezmiernie dziwi, ponieważ uznawał, że „po minionym periodzie poezji egoistycznej próżność poetyczna już nie jest w modzie". Nie tylko zatem egotyzm romantyczny, ale i frenezję ujrzeć można na łamach „Nadwiślanina”, jako że tu znowu prym wiódł Zmorski, który przeraził recenzenta powieścią Dziewica-widmo (,żaden Bramin indyjski nic potworniejszego wmyślić by nie mógł"), trochę jednak ochłonął, czytając prace Keniga. Niewiele dobrego napisać mógł recenzent o naukowych, szczególnie zaś historycznych i filozoficznych pracach, które na łamach pisma się ukazały. Zdaniem jego była to najsłabsza część „Nadwiślanina”, choć pewność i śmiałość w wyrażaniu sądów niemało imponowała recenzentowi. Ostateczna jednak ocena pisma w oczach „Biblioteki” wypadła pozytywnie, sąd swój zakończył anonimowy krytyk stwierdzeniem, że niepodobnym jest, ,aby z tego zarodu coś dobrego wysnuć się nie mogło, dlatego oczekujemy cierpliwie na dalsze poszyty" ${ }^{20}$.

$\mathrm{Na}$ kartach „Nadwiślanina” nie zabrakło prac warszawskiej bohemy, pismo nie zamykało się bowiem szczelnie jedynie wokół postaci czterech cyganów, ale udostępniało swoje łamy publicystom z różnych stron kraju, dzielącym wraz z nimi poglądy. W pierwszym tomie wśród autorów dzieł poetyckich odnaleźć można Filleborna właśnie (Fantazja; Użalenie; Powrót; Do myśli; Pieśń gminna; Do Wisty), Zmorskiego (Do** [Nawiazanie]), Gustawa Zielińskiego (Do dziewczyny; Do myśli; Sztuki piękne), Balińskiego (Porada; Kiedy się thumy zbiora $i$ w podtym wykrzyku [inc.]), Szymanowskiego (Niewolnica; Fantazja), Juliana Korsaka (Rozkosz i boleść), Pola ( $W$ imionniku), Lenartowicza (Czy widziałeś te osty, co na gruzach rosna [inc.]), Dłużniewskiego (Dwa glosy), Samueliny (Dumanie), Wiktoryna Zielińskiego (Piosenka myśliwska; Poranek I), Skotnickiego (Piosnka). Twórczość, która w oczach redakcji została określona jako proza (wśród niej również recenzje i doniesienia dotyczące najnowszej literatury) była autorstwa Sierpińskiego (Gierada, Hergewet, Wiano, Posag, Dziedzictwo u dawnych mieszczan w Polsce; Adam Bursiusz; Stawa; Historia Pana Bartosza

19 Ant. F. [A. Filleborn], Odpowiedź „Bibliotece Warszawskiej” na jej krytykę o „Nadwiślaninie”, „Nadwiślanin” 2, 1841, s. 85.

${ }^{20}$ Zob. Trz, op. cit., s. 474-476. 
[Z prawdziwego opowiadania]), Majorkiewicza (Periody dziejów filozofii; Jakób Górski; Rozporządkowanie dziejów Filozofi; Myśli i Uwagi; O ciemności pism filozoficznych niemieckich), Zmorskiego (Pisma periodyczne $w$ Warszawie literackiej treści; Dziewica-widmo (z podania)), Keniga (Sztuka i artyści; Szynki! baranki! [rycina Piwarskiego]; Konik Zwierzyniecki) i Filleborna (Wiadomości literacko-naukowe). Tom drugi, znacznie uboższy, wypełniły dzieła poetyckie Szymanowskiego (Sen poety), Brzozowskiego (Gołabek [naśladowanie z litewskiego]), Wiktoryna Zielińskiego (Rezygnacja poety), Filleborna (Dla ubogich), Żeligowskiego (Z melodii litewskich; Tęsknota) i Lenartowicz (Dumka). Prozę reprezentował Sierpiński (Miasto Grabowiec), Dziekoński (Moja fajka [marzenie]; Pająk [urywki z listów młodego artysty]), Skotnickiego (Wojciech Piasecki), Chałubińskiego (recenzja) i Antoniego Filleborna (odpowiedź „Bibliotece”).

Paleta twórców, choć dostatecznie szeroka, nie zapewniła „Nadwiślaninowi” sukcesu na rynku prasowym, postawiła go jedynie w rzędzie obok innych „Wianków” czy „Niezapominajek”, które tęsknymi balladami, banalnymi lirykami, żalami poety nad samotnością, światem, ludzką chciwością, niestałością kobiecego serca i strachem przed przyszłością ujmowały przeciętnego czytelnika.

Kiedym myśli oddawał, moich marzeń kwiaty,

Gdym z połowy mej duszy raj ziemski osnował,

I połowę tych uczuć dla świata darował,

Wy uczuć nie pojęli; kwiat marzeń bogaty,

wyśmiali, wyszydzili i z zimną rozwagą,

Ukazali mi prawdę ponurą i nagą.

I dziś nie mam już myśli — bo kiedy jak we śnie,

Wymuszoną odpowiedź rzucę pośród ludzi,

To tak dzika, prostacza, tak brzmiąca boleśnie,

Że albo wstrętem przejmie, albo śmiech obudzi ${ }^{21}$.

Smutki poety rozpraszały utwory opiewające piękno i czar ziemi mazowieckiej, te pełne nadziei, gminne, ludowe, bliskie wieśniaczej prostocie, naturze, wyidealizowanej małej nadwiślańskiej ojczyźnie. Teksty te opiewały znane poetom z wędrówek tereny, które stawały się dla nich osobliwym rajem na ziemi, zbudowane jednak były z tkanki patriotycznej, niewidocznej gołym okiem dla cenzora $^{22}$, zza której kryła się nie tylko tęsknota do ziemi mazowieckiej, ale i wolnej ojczyzny. Cenzura skutecznie jednak okuła w dyby poetów, swoje pragnienie buntu, rewolucji i działania wyrażać musieli frazami obleczonymi w ka-

21 S. Filleborn, Użalenie, „Nadwiślanin” 1, 1841, s. 14-15.

22 O języku ezopowym, w którym wypowiadała się Cyganeria Warszawska, wspominał Niewiarowski: „Pamiętać należy, że od owej epoki rozdziela nas już pół wieku prawie i że ówcześni poeci musieli wytwarzać sobie nowy, rzec by można: symboliczny język, a raczej styl może, którym... tylko »czułym słuchaczom«, dla »dośpiewania w duszy«, myśli i przekonania swoje wypowiadać mogli”. A. Niewiarowski, Cyganeria warszawska, [w:] W. Szymanowski, A. Niewiarowski, Wspomnienia o Cyganerii Warszawskiej, zebrał i opracował J.W. Gomulicki, Warszawa 1964, s. 263. 
muflaż, posługiwali się językiem konspiracyjnym, ezopowym ${ }^{23}$, hieroglificznym, dostatecznie jednak zrozumiałym, bogatym w słowa klucze rozpoznawalne dla czytelnika $^{24}$. Pojawić się zatem musiała metafora burzy, a wraz z nią piorunów, błyskawic i gromów, obok nich żeglarzy, wypływających na wzburzone wody śmiałków, ochotników, pielgrzymów, wędrowców, najczęściej samotnych tułaczy, młodych jednak, pełnych zapału, którzy pośród zwalisk, ruin, zardzewiałej już broni oczekiwali sygnału, którzy pozostawiali w domach swoich ojców, swoje matki strapione, by ogniem zapowiedzieć wiosnę w ojczyźnie. Echa utraty, poczucia pustki i niezrozumienia pojawiały się również w prozie Majorkiewicza, który gmin wywyższał, jego z poetą swatał i oddawał mu pierwszeństwo w zrozumieniu słów wieszczych, odbiera ją zaś wszystkim czcicielom bałwanów złota, tym miłośnikom tanich rozrywek, bibelotów, świecidełek, jarmarcznych rymowanek okraszonych śmiechem zza kufla z bawarem. Podobne wyrzuty odbiorcom czynił Dziekoński, który w listach młodego artysty kpił z domorosłych kosmopolitów, w których domach ,rozmawiano po francusku. Śpiewano po włosku. Tańczono po niemiecku. Jedzono kolację po angielsku", sam zaś bohater jedynie milczał

23 Język ezopowy. Zob. M. Janion, Wstęp, [w:] Antologia romantycznej poezji krajowej (18311863), oprac. M. Grabowska, M. Janion, Warszawa 1958, s. 29. Na temat języka ezopowego zob. również Z. Przybyła, Nauka o języku w szkole. Odzyskany termin „język ezopowy”, „Język Polski” 1994, nr 4-5, s. 320-331; M. Ryszkiewicz, Mowa ezopowa w felietonach Kisiela, „Pamiętnik Literacki” 2002, nr 1, s. 113-135; B. Sułkowski, ,,Ten przeklęty język ezopowy”. O społecznych mechanizmach komunikacji cenzurowanej, [w:] Piśmiennictwo, systemy kontroli, obiegi alternatywne, t. 2, red. J. Kostecki, A. Brodzka, Warszawa 1992, s. 266-284; F. Ramotowska, Sto lat „,cenzury rzadowej" pod zaborem rosyjskim (1815-1915) - podstawy normatywne, instrumenty wykonawcze, [w:] Piśmiennictwo - systemy kontroli - obiegi alternatywne, t. 1, red. J. Kostecki, A. Brodzka, Warszawa 1992, s. 122-174; J. Smulski, Kostium historyczny w popaździernikowej prozie rozrachunkowej, „Acta Universitatis Nicolai Copernici, Filologia Polska” 49, 1997, s. 19-51.

24 Posługiwanie się przez twórców językiem ezopowym sprawiało często, że cenzorzy prześcigali się w wyszukiwaniu aluzji, jednocześnie do perfekcji opanowując umiejętność wyszukiwania nawiązań politycznych. „Najlepiej charakteryzuje ówczesny system cenzuralny następujący fakt: książę Paskiewicz dawał bal; »Kurier« podając opis tego balu, wspominał, że na schodach zamkowych stał rząd przepysznych drzew pomarańczowych z oranżerii łazienkowskich. Cenzor czytając tę wiadomość, w słowie »rząd « poprawił $\mathrm{R}$ na wielką literę i dopisał przed nim »opiekuńczy«. Czytaliśmy więc nazajutrz w »Kurierze«, że »Na schodach zamkowych, u wejścia do sali balowej, stał Opiekuńczy Rząd wspaniałych drzew pomarańczowych «". Wykluczone było stosowanie słowa „rewolucja”, określenie zaś „niewolnik” zamieniano rychło na „Murzyna”, tworząc kolejne kurioza: „niewolnik swoich namiętności” stawał się „Murzynem swoich namiętności”. Zakazany był również kolor pomarańczowy, ten bowiem zdobił kołnierze mundurów policji; niedozwolona była prognoza pogody („Dziś deszcz pada, a na jutro zapowiada się pogoda”), bo zapowiadać mogła zmiany, podobnie jak cudownie uczynione jakieś rzeczy, cudów bowiem nie było i nie należało się ich spodziewać. W końcu ludzie pióra, w akcie najwyższej desperacji, gdy nie wiedzieli, o czym pisać, wszystkie bowiem ich teksty przez cenzury przejść nie mogły, udali się do Muchanowa, który zasugerował, by o wężu morskim pisali, który od tego czasu stał się symbolem cenzuralnej ,rzezi”. Zob. A. Zaleski, Towarzystwo warszawskie. Listy do przyjaciólki przez Baronowa XYZ, oprac. R. Kołodziejczyk, Warszawa 1971, s. 333-336. 
po polsku ${ }^{25}$. Nie sposób nie dopatrzyć się w uciekającym z salonu poecie samego autora, który również czmychnął z wykwintnego spotkania u Katarzyny Lewockiej, by później, wraz z Fillebornem odbyć wielką peregrynację po szynkach warszawskich ${ }^{26}$.

Dokoła długie stoły i ławy zastawione butelkami i kuflami, kilku obdartych ludzi, dalej dorożkarz, baba z obwarzankami, weteran, oto był pozór całego miejsca. Spojrzeli się po mnie i czy mam ci powiedzieć? zawstydziłem się? wstyd mię było mych sukien. Zazdrościłem im w tej chwili obdartych łachmanów, jakby ten frak czarny był jakimś piętnem, jaką nieprzepartą zawadą do połączenia się i zbratania z gminem, ich wzrok wyrzucał mi różność kasty, spoglądali na mnie tak, jak spoglądać musieli Ilotowie na swych dumnych panów idących na Forum! ${ }^{27}$

Poza poezją i poza prozą leżała jeszcze dziedzina recenzji, która na łamach „Nadwiślanina” była uprawiana — wobec dzieł nowych, które brano pod lupę, unikano słów ostrych i cierpkich, te zostawiano bowiem dla największego adwersarza cygańskiego dziecięcia — „Biblioteki Warszawskiej”. Na recenzję „Nadwiślanina” w piśmie Szabrańskiego odpowiedział sam Antoni Filleborn, nie szczędząc przy tym słów obraźliwych, nazywając „Bibliotekę” „,bigosem literackim, olbrzymim piernikiem toruńskim lub czym podobnym"28, która obleka się nie w białe, lecz brudne okładki. Również w obronie Kraszewskiego stanął „Nadwiślanin” i nie pozwolił, by „Biblioteka” wymierzała pociski w autora Poety $i$ świata, uznając jej krytykę za fałszywą, niewłaściwą, stronniczą ${ }^{29}$. Naraził się tym samym „Nadwiślanin” zwolennikom „Biblioteki”, szczególnie zaś osobie Edmunda Chojeckiego, który na łamach „Echa” wystosował mowę przeciwko cygańskiemu pismu.

Poezje P. Filleborna są pełne życia; wszędzie przebija się w nich niepospolita zdolność młodego pisarza, bujna wyobraźnia i serce rzewnymi przepełnione uczuciami. Budowa zewnętrzna wiersza jest dźwięczna, sposób objawiania myśli nader zajmujący. Następny wiersz p. Zmorskiego jest zupełnie słaby. Nie można p. Zmorskiemu odmówić wiele czucia, wiele wyobraźni, ale życzymy mu szczerze, aby się bliżej poznał z gramatyką. [...] A przy tym jakieś ni w pięć ni w dziewięć kantyczkowe porównania, jak np. pędzli do berła, są albo tak głębokie, że ich pojąć nie potrafimy, albo też całkiem niestosowne. Pominąwszy Dziewicę-widmo, którą czytając aż włosy wstają na głowie [...]. Mógłby jaki pedant zarzucić, że chcąc osądzić obszerne 4 tomy tak różnorodnego pisma trzeba więcej nad kilkanaście wierszy napisać, ale radzimy szczerze „Nadwiślaninowi”, aby niczyich rad nie słuchał, postępował, jak mu się zdaje i przyjął za zasadę: choć krótko, lecz dobrze. Zaiste, jaka

25 J.B. Dziekoński, Pająk. Urywki z listów młodego artysty, „Nadwiślanin” 2, 1841, s. 41.

26 Aniela Kowalska w epizodzie z Pająka odnajduje również inne aluzje: „Nie można nie docenić wymowy tego opowiadania, zawartego w formie listowych wynurzeń. Zawierają one bowiem nie tylko pewne akcenty autobiograficzne jej autora, ale także wyraźne sugestie do realizowanego w owych latach warszawskiego spisku plebejskiego. To trudne dziś niekiedy do rozszyfrowania aluzje i napomknienia zasługują na uwagę". A. Kowalska, $W$ kręgu „Nadwiślanina” i „Przeglądu Naukowego”, „Zeszyty Naukowe Uniwersytetu Łódzkiego. Nauki Humanistyczno-Społeczne” 1968, z. 55, s. 8 .

27 J.B. Dziekoński, op. cit., s. 44.

28 Ant. F. [A. Filleborn], op. cit., s. 85.

29 Anonim [R. Zmorski], Pisma periodyczne w Warszawie literackiej treści, „Nadwiślanin” 1, 1841, s. 48. 
szkoda, że Goethe umarł, byłby doczekał się najświetniejszej chwili, byłby ujrzał Nadwiślanina w rybackim stroju, z napuszoną jak jędyk [indyk — przyp. D.S.] miną, z wzniesionym wiosłem nad głowę, występującego do walki z każdym uwłaczającym honorowi wielkiego mistrza ${ }^{30}$.

Na nic jednak były prometejskie czyny „Nadwiślanina” — „Biblioteka” bowiem sprowokować się nie dała i działania młodych cyganów odebrała jako jedno z wielu buntowniczych wystąpień, które nie są w stanie obalić bastionu, jakim było pismo Szabrańskiego. Nie zdążył nawet „Nadwiślanin” odpowiedzieć Chojeckiemu, ponieważ po sześciu numerach pismo przestało istnieć, jak uznawał Szymanowski, z winy Filleborna, który i tym razem zbyt wiele sobie, ale też innym cyganom piwa nawarzył - ,się rozprzęgło towarzystwo jego redaktorów, którzy koniec końców nazbyt lubili hulać, żeby wytrwać w porządnym wydawaniu pisma, ale sympatia publiczności otaczała go do końca istnienia"31.

Nie koniec jednak na tym cygańskiej działalności wydawniczej, jeszcze bowiem nadzieja się tliła, że rynek podbiją młodzi zapaleńcy, a i kiesa Dembowskiego wciąż była pękata, sugerując wsparcie nawet w wypadku początkowego niepowodzenia. Spróbował zatem Zmorski z Dziekońskim stworzyć pamiętnik nowy, który nie tylko cyganów, lecz także ogołocyganeryjnej młodzi pisma by zawierał. Tak też w 1843 roku powstała Jaskułka ${ }^{32}$, w podtytule określona jako pamiętnik, wydrukowana, podobnie jak „Nadwiślanin”, u Maksymiliana Chmielewskiego w formacie ósemki jako ponadstusiedemdziesięciostronicowa książeczka, wydana nakładem Orgelbranda, dostępna za 5 złp. Sprzyjający cyganom „Przegląd Naukowy" z otwartymi ramionami powitał ją na rynku wydawniczym, zaraz obok krakowskich „Rozrywek umysłowych”, wileńskich „Zniczy” i „Birut”, petersburskiej „Niezabudki”, żmudzińskiej „Linksmine”, poznańskiego „Roku” i „Świętojanki”, warszawskiego „Pierwiosnka” i „Niezapominajek”, Jaskułke jednak uznając za „pierwsze dobre pismo zbiorowe"33. Docenia bowiem recenzent, że młodzi twórcy „nie zasłaniają się [...] imionami znanych, sławnych, znakomitych", nie pragną również przyciągnąć czytelnika zewnętrzną formą pisma, gdyż zrezygnowali z welinowego papieru, ozdobnych berlińskich czcionek, paryskich winietek, złoconej oprawy na rzecz zwykłego papieru i prostego wydania. Wśród autorów, z których dziełami na łamach pamiętnika można się zapoznać, a którzy ofiarowali je, nie oczekując na honorarium, ponieważ redakcja takiego nie wypła-

30 Anonim, [recenzja], „Echo” 1841, nr 1, s. 7.

31 W. Szymanowski, Literaci warszawscy, [w:] W. Szymanowski, A. Niewiarowski, op. cit., s. 163.

32 Niepoprawny z obecnego punktu widzenia zapis tytułu pamiętnika cygańskiego wytłumaczyć można ewolucją, jaką wyraz przeszedł w XIV i XV wieku, kiedy został po raz pierwszy odnotowany (dysymilacja prasłowiańskiego rdzenia *last-) oraz w XV i XVI wieku (wymiana morfemu -oł- na -uł-). Zapis jaskułka (spotykany dawniej) był znacznie rzadszy od dzisiejszej jaskółki, przetrwać mógł w tradycji regionalnej lub gwarowej i być może z niej właśnie cyganie taką formę zaczerpnęli. Tym sposobem zapisu posługiwał się również Wójcicki. Za sugestie dziękuję prof. Mirosławie Siuciak.

33 Zob. Anonim, [recenzja], ,Przegląd Naukowy” 1843, nr 22, s. 161-162. 
cała, wymienić należy poetę Antoniego Czajkowskiego (Pająk), Filleborna (Trzy światy), Lenartowicza (Tęsknota; Wiersz napisany na tafli kamiennej w pieczarach cmentarza; Dwa pogrzeby), Zmorskiego (Topielce; Myśl; Aniot-Niszczyciel; Sny i Przebudzenia; Wieszcz; Pieśń), Niewiarowskiego (Strach [baśń gminna]) i Wolskiego (Zadumka; ** noli me tangere; Celia - urywek). Prozę zaś, zgodnie z mechanicznym podziałem zastosowanym w „Nadwiślaninie”, reprezentowali Dziekoński (Łysa Góra, wspomnienie z wędrówki po kraju; Trupia głowa na biesiadzie - fantazja z podania gminnego; Okiennik, wspomnienie z wędrówek), Dembowski (Kilka stów o poemacie dramatycznym samorodnym), Sierpiński (Rys dziejów Akademii Zamojskiej [z pozostałych rękopisów]) oraz Wolski (Skrzypce, powiastka).

Z niezwykłym entuzjazmem powitał na łamach „Przeglądu Naukowego” $J a-$ skułkę również sam Dembowski, nie szczędząc przy tym słów pochwały i uznania, jednocześnie karcąc twory rozbrykanego grona.

Ile tu rozstrzelonych dążeń, jak zupełny brak całości, jedności, jak rażąca niewyrobioność podsad myślowych i zbywanie naukowego stanowiska; na usprawiedliwienie pracowników to powiedzieć można, że zwykły los myśli młodych jest wzlotem poezji bez podsady naukowej; ale co usprawiedliwia pisarza, nie zmienia stanowiska, jakie zajmuje dzieło jego. Stąd „Jaskółkę” ceniąc, z sercem bratnim witamy jako symptom już silnej w zarodach nowej szkoły literackiej, symptom tym ważniejszy, że choć nie jest budzących się dążeń organem, jest ich drgnieniem żywotnym; stąd także, przy jej bezwzględnym ocenieniu, bolejemy nad rozstrzeleniem jej pojedynczych części, nad brakiem harmonii w całości i nad tym, że jest tylko poezją i beletrystyką zapełniona ${ }^{34}$.

Chwalił Dembowski Sierpińskiego za rodzynek naukowy, który na łamach Jaskułki się ukazał (,jedyny poważniejszy półdziejowy artykuł”), jednak poruszone zagadnienie już takich emocji w czerwonym kasztelanicu nie wywołuje, jak bowiem popierać pracę o ośrodku jedynie dla możnych przeznaczonym, przeciwnemu zadaniu „uspołecznienia ludu”, pełnego ,żywiołów przeciwludowych”? Nie oszczędzał również Dembowski Dziekońskiego, któremu zarzucał, że „brnie w kał wsteczności”, zamiast „kochać całą duszą lud i ludzkość”, wolał „straszyć poczciwych filistrów i magiczną latarką swego pióra pojęcia zgniłe gwałtem w światła przybierać sukienki". Przeciwne jednak zdanie ma na temat prozy Wolskiego, która w jego oczach „pełna wdzięku i uroku”, ,miejsc pojedynczych zachwycających”, jednak pozbawiona jest „myśli dzielnej”, która mogłaby z niej uczynić twór wiele wart dla ducha. Jednak nietrudno w poezji odnaleźć Dembowskiemu takie dzieła - Niewiarowskiego wiersz określił mianem poronionego i nędznego, chwalił Lenartowicza, choć jego utwory „mniej poetycznymi są”, za dobre uznał strofy Czajkowskiego ${ }^{35}$, Wolskiego i Zmorskiego.

34 E. Dembowski, Jaskułka. Pamiętnik wydany przez R. Zmorskiego i J.B. Dziekońskiego. Przeglą, [w:] idem, Pisma, t. 3. Pisma ogłoszone w roku 1843, red. A. Śladkowska, M. Żmigrodzka, Warszawa 1955, s. 332-333.

35 Utwór Czajkowskiego Pająk uznany został przez Dembowskiego za „niezrównanej piękności”, stanowi przykład zaniedbania cenzora, który nieopatrznie udzielił zgody na druk tego kryptopolitycznego wiersza, w którym określone typy pająków odnoszą się do przybieranych przez 
Wieszcza Romana Zmorskiego kładziemy na pierwszym miejscu. Poeta wystawia nam wrzących uczuć młodzieńca, który samą potęgą swojego ducha władnie nad wszystkimi. [...] Potęgą własnego ducha wzlatuje młodzian, urąga zawistnym głosem ziemi i burzom, i duchom ciemności, i potęgę dobroci nawet łamie. Pieśń Zmorskiego krótka, lecz szczególnym, właściwym mu wdziękiem poetycznej mowy ubarwiona. Aniot-Niszczyciel odznacza się potęgą i dziką, szaloną wściekłością ${ }^{36}$.

Podsumowując swoje wywody, Dembowski nie miał dla cyganów dobrych wieści, stwierdzał bowiem, że Jaskułka to ,zbiór bezbarwny prawie”, nie ma w nim rysu wspólnego dążenia, celu, harmonii. Był to kolejny owoc wspólnej pracy warszawskiej szkoły, młodej piśmienności, która, ma on nadzieję, kiedyś stworzy własny organ, gdzie publikować będą dzieła dojrzalsze, godne wysokiej, a nie tak niskiej oceny ${ }^{37}$. Zawiedziony, rozczarowany, ale jednak pełen wiary Dembowski ufał cyganom zapewne i wierzył, że kiedyś gotowi będą stworzyć zbiór wyższych lotów — niestety! spiski, śledztwa, szpiegostwo, aresztowania, ucieczka z Królestwa przekreśliły jego nadzieje. I choć Jaskułka była łabędziem śpiewem cyganerii na rynku czasopiśmienniczym, nie oznaczała ona końca współpracy zapaleńców z wydawcami, nadal bowiem oczekiwał na nich ,Snopek Nadwiślański”38, krytykowana wielce „Biblioteka Warszawska”39, twór „,wujaszka Wilka” „Dzwon Literacki”, a przede wszystkim „Przegląd Naukowy”40.

A wiele jeszcze było prac w tece redakcyjnej, być może i cygańskich, choć jeno dwóch z nich miało okazję pod Najgłupszym służyć, resztę błaznów bowiem wiatr rozwiał już po świecie i tam, i tu, by błąkali się w wiecznej tułaczce z rękopisem pod pachą, czy o mieście Lublinie, czy niespełnionej miłości albo i o szczęściu, którego nie było w ojczyźnie. A cenzura jeno zęby na nich ostrzyła, cytadela zapraszała w swoje progi i strach blady padał wówczas na spiskujących, a przecież sami byli sobie winni. Niegłupi woźny już przecież dziesięć lat temu rozprowadzał ulotki, w których napisał wyraźnie „Nie trzeba było książek pisać, miałby u nas inszą uwagę". Albo o kwiatkach, albo o pasztetach chociaż, wtedy bezpieczniej.

Polaków-patriotów postaw. Cenzorskie niedbalstwo próbowano później nadrobić, tępiąc wszystkie utwory, nawet te zupełnie niewinne, gdzie tylko pająk się pojawił. Zob. J. Kamionkowa, Życie literackie w Polsce w pierwszej połowie XIX w. Studia, Warszawa 1970, s. 264.

36 E. Dembowski, Jaskułka..., s. 337.

37 Ibidem, s. 338.

38 Zob. W. Wolski, Elegia, Do urojeń, Rozkosz, „Snopek Nadwiślański” 1844; J.B. Dziekoński, Wyzwolenie zapaleńca, „Snopek Nadwiślański” 1845; R.Z. [R. Zmorski], Wyjątek z dramatu fantastycznego Lesław, „Snopek Nadwiślański” 1845.

39 Zob. S. Mękarski, O genezie „Biblioteki Warszawskiej” i jej charakterze w latach 18411863, „Pamiętnik Literacki” 1925/1926, nr 22/23, s. 484-498.

40 Zob. M. Straszewska, Czasopisma literackie w Królestwie Polskim w latach 1832-1848, część druga (1840-1848), Wrocław 1959, s. 59. Zob. również J. Kucharzewski, Czasopiśmiennictwo polskie wieku XIX w Królestwie, na Litwie i Rusi oraz na emigracji, Warszawa 1911, s. 47-54. 


\section{Warsaw's Bohemie publishing attempts or "homely" magazines review. From the perspective of the Warsaw's province}

\section{Summary}

The years 1831-1863 in the Polish Kingdom were marked by the atmosphere of anxiety, fear, fear of tomorrow and regret for what has passed. Warsaw's Romantics, existing in their own literary world of far provinces, were facing the challenges of their profession - to overcome the stagnation, get out of lifelessness - with difficulty. Enthusiasts, young gypsies who have grown under the wings of Hippolytus Skimborowicz were engaged in publishing, mobilized all their forces to - in spite of the words of Zygmunt Krasinski, who believed that "now in Poland of flowers and patties one can only write" - create a new style of periodicals. Little articles written by "young enthusiasts", poetic creations written in esopic language, not always the best reviews of filled the columns of the magazines - critically evaluated by Edward Dembowski. Existence of publishing work was not easy - it had to stand against censorship, copyrights, and above all, capricious tastes of readers. Magazine's lifespan was not long, it was however the testimony of struggle against the things that terrified and aroused horror. 